\title{
Presidential Proposals in Congress
}

\author{
Nicholas Kayler \\ Georgetown University, Washington, D.C., USA
}

\begin{abstract}
This paper analyses what is likely to happen to a presidential proposal once it has been introduced in Congress. By analysing the efforts of Presidents Bill Clinton and Barack Obama to pass comprehensive healthcare reform, this paper argues that the ideological spread in the House of Representatives and the Senate, the influence wielded by interest groups, and the nuanced responses of both parties in Congress to presidential proposals are all of fundamental importance to the chances a presidential proposal has of eventually becoming law. Given the success of the Obama administration and the failure of the Clinton administration to succeed in passing fundamental healthcare reform, these two cases can provide the field of political science with a convincing account of what a presidential proposals eventual fate will be.

Keywords: Congress, healthcare, Clinton, Obama, presidential proposals
\end{abstract}

\section{Introduction}

The conventional wisdom surrounding the relationship between the president and Congress holds that the president will get the support of his own party and that he will rarely, if ever, succeed in bringing members of the opposition party on board with a specific piece of legislation. While it is true that members of Congress are reluctant to oppose a president if he is a member of the same party (and similarly unlikely to vote with him if he is a member of the opposite party), the notion that a bill will pass or fail depending on the president's position leaves many questions unanswered. This paper will argue that the importance of the ideological spread in Congress, the influence wielded by interest groups, and the nuanced responses of both parties in Congress to presidential proposals are all of fundamental importance to the chances of a bill passing into law. In order to do this, the efforts of presidents Bill Clinton and Barack Obama to pass fundamental health care reform will be analyzed.

\section{Literature Review}

The amount of literature analyzing presidential versus congressional relations is expansive. In this section, the strengths and inadequacies of this body of knowledge will be outlined, and the ways in which this research design will build upon this knowledge will be indicated.

In "Dividers, Not Unifiers: Presidential Leadership and Senate Partisanship, 1981-2004", Frances Lee furthers many standard notions surrounding the relationship between the president and Congress. She argues that "presidential successes create credit-claiming opportunities for the president's party", and that "a president's fellow partisans recognize that they have an interest in making him look good" (Lee, 2008a, p. 914). The statistical analysis revealed by Lee's methodology provides insight into why many people place so much

Nicholas Kayler, M.A., Department of Government, Georgetown University. 
emphasis on the impact of the president in the legislative process. Based on her findings, approximately $40 \%$ of Congressmen use the president's position on an issue as their primary cue in determining how they vote, as the president's position acts as a "decision-making heuristic" (Lee, 2008a, p. 916). This research design is an attempt at expanding on the helpful, but incomplete findings, of political scientists like Lee. Her assertion that members "who generally approve of the president are likely to give his policies the benefit of the doubt, [while] those who generally disapprove of the president will be less inclined to support his policies" (Lee, 2008a, p. 916) certainly holds true in many circumstances, but does not account for historical anomalies like Bill Clinton's attempt at passing the Health Security Act (HSA).

This notion is present in Beyond Ideology: Politics, Principles, and Partisanship in the U.S. Senate, which is another work of Lee. Lee (2009) asserts that many members of Congress will take strictly partisan positions on presidential issues, as failing to do so may be construed as that particular member wavering between conservative and liberal principles (p. 52). To provide readers with an example of how this inclination has somewhat contradictory outcomes, Lee analyzes the vote of the expansion of Medicare to cover prescription drugs in 2003, and how Republicans supported George W. Bush in spite of the policy being antithetical to mainstream Republican ideology (Lee, 2009, p. 52). This is helpful in arguing that nuance and subtlety exist in the relationship between the president and Congress, and will be revisited when the decision of 34 "blue dog" Democrats to vote against the Affordable Care Act (ACA) is discussed in the data and methodology section.

In "Congressman's Voting Decisions", John Kingdon argues that Congressmen belonging to a specific party are incentivized to follow the wishes of the president if they belong to the same party, and that "this attachment to the administration [is] grounded in the fact that they had personally campaigned long and hard for [the administration] and thus has quite an emotional commitment to [their party's] president once elected" (Kingdon, 1989, p. 180). By interviewing Congressmen in both parties, Kingdon determined that similar logic governs their behavior. Quoting one unspecified Congressman, Kingdon (1989) captures the mood many of them have in regards to presidential initiatives: "when my guys are in the White House, the vote is close, and they need my vote, then I'll go along. But when there are there, and they've always voted against my guys out of political motives, then why should I go along with them?" (p. 181).

While indicating the importance of this dynamic between the president and Congressmen on both sides of the aisle, Kingdon (1989) sees the relationship between Congressmen themselves as the most important influence on eventual voting decisions, as Congressmen and their colleagues are "apt to supply the type of information most useful to [one another]", which is "digested, explicitly evaluative information which takes account of politics as well as policy implications of legislative issues" (p. 101). Furthermore, Kingdon's methodology reveals the partisan nature of the relationship between Congress and the president. According to his findings, Republicans "without prompting from a question, bring up the administration position and activity fully $42 \%$ of the time", which is considerably higher than their Democratic colleagues in the House of Representatives and the Senate" (Kingdon, 1989, p. 185). Kingdon's analysis accurately depicts the predilections of many members of Congress in terms of how they respond to presidential proposals, but offers little in terms of why partisans will break with historical patterns and vote against their president or for an opposing president.

In "Agreeing to Disagree: Agenda Content and Senate Partisanship", Frances Lee (2008b) argues that the shifting agenda in Congress has resulted in an increase in Senate partisanship, and argues this by analyzing the issues that made it onto the Senate roll-call agenda from 1981-2004 (p. 199). This "institutionalization" of 
parties in Congress has promoted non-decisions in the legislative process (Lee, 2008b, p. 202). According to Lee's (2008b) methodology, economic issues in the Senate are much more polarizing than many other issues, and have become more prominent on the Senate agenda (p. 205). Lee (2008b) cites statistical data that points to conservative Republicans supporting measures that limit the government's share of the economy, which includes healthcare related policy areas such as social security, Medicare, and a number of other "privatization initiatives" (p. 207). Over the time period in which she studies, Lee (2008b) informs readers that blanket economic issues have become 55\% more prominent on the Senate agenda, and that the two parties battle the most over "economic issues of taxation, redistributive social programs, economic regulations, and the government's share of the economy (pp. 210-211).

This reality is helpful in understanding both the HSA and the ACA, as in both cases, Republicans in the Senate were quick to decry the legislation as dangerous increases in governmental intervention in the lives of Americans. In terms of presidential proposals, Lee (2008b) argues that "if senators take into account how their votes will affect the president's and their own party's image, then presidential agenda items are likely to spark higher levels of partisanship" and that the "distance between the two parties is likely to be greater on each of these types of votes" (p. 213). While the words of Lee provide an applicable guidebook for the legislative fortunes of the ACA, its applicability to the HSA is comparatively limited, which is a shortcoming that will be addressed in the hypothesis section of this research design.

\section{Hypotheses}

The hypothesis for this research design is as follows: Presidential proposals will be decidedly more likely to pass through Congress when the president party possesses a filibuster proof majority in the Senate, when enough compromise has been made with powerful interest groups and lobbyists, and when the issue is domestic in nature. An absence of any combination of these factors will likely spell the demise of a presidential proposal regardless of how forceful the president advocates its merits to the American people.

A possible counterhypothesis to this is the prevailing notion surrounding the relationship between the president and his Congressional colleagues: A bill will pass if a president's party has a majority in both the House and the Senate, but will struggle to get much done if the other party has a majority. An additional counterhypothesis is the notion that the above conditions are less relevant in terms of foreign policy issues. As prominent scholars such as Canes-Wrone et al., have convincingly argued, it is well known that a president can enjoy an increase in bipartisanship in times of crisis short of having the aforementioned advantages, with the post 9/11 era under George W. Bush serving as a recent and prominent example (Canes-Wrone, Howell, \& Lewis, 2008, p. 14).

To test this hypothesis, and to account for the counter hypotheses, I will look at the ideological spread in both Houses of Congress during the attempts to pass the HSA as well as the ACA. Furthermore, the activity of interest groups and lobbyists throughout both legislative efforts will be given their due consideration.

\section{Data and Methodology}

In order to test my theory that the activity of interest groups has a considerable effect on whether or not a presidential proposal will pass into law, I have consulted a variety of sources that analyze their activity during the HSA as well as the ACA. These sources will also be used to account for the counterhypothesis asserting that the makeup of Congress is the lone determinant of a bill chance at legislative success. 
In The System: The American Way of Politics at the Breaking Point, authors Haynes Johnson and David S. Broder provide a significant amount of qualitative evidence that points to my hypothesis being true in the attempts of the Clinton administration to pass the HSA. In their book, they argue that the "groups who mobilized to fight the Clinton Plan included not just those with the most direct economic stake in the outcome, like the Health Insurance Association of America (HIAA), the Healthcare Leadership Council, the Business Roundtable, and the National Federation of Independent Business (NFIB), but such seemingly disinterested organizations [such as] Pat Robertson's Christian Coalition” (Johnson \& Broder, 1996, p. 197). Deborah Steelman, a former George H.W. Bush administration official turned lobbyist, described this onslaught of industry opposition to the Clinton's plan for healthcare reform as a "lineup of the stars [that] you don't get in politics very often" (Johnson \& Broder, 1996, p. 197).

Recognizing their ability to scuttle reform, the HIAA launched a three-and-a-half million dollar advertising campaign that aimed to undermine the HSA's chances at legislative success (Johnson \& Broder, 1996, p. 204). This effort on the part of industry went straight to the source of legislation in the country. This HIAA alone "produced more than four hundred fifty thousand contacts with Congress [in the form of] phone calls, visits, or letters", which amounted to "almost a thousand to every member of the House and Senate" (Johnson \& Broder, 1996, p. 213). This brand of negative messaging had direct implications for how Congress responded to the overall attempts at legislation. This aggregation of interest groups who were "opposed to change were spectacularly successful in making government appear to be the enemy", as their "ability to exploit and to heighten [negative] attitudes about government was critical to their success [in killing the legislation]" (Johnson \& Broder, 1996, p. 207). President Clinton's failure to garner the support of interest groups helps to prove the veracity of my hypothesis. A steady stream of opposition from powerful interest groups will invariably hurt the chances of a bill passing into law. Furthermore, this failure also works to oppose the competing hypothesis that a presidential proposal will pass into law if the president has a majority in both chambers of Congress, which is a point that will be revisited in this section.

As it relates to the ACA, the way in which interest groups impacted the legislative was considerable, but different, in comparison to the HSA. While the opposition to the HSA from interest groups was substantial, neither Bill Clinton nor the First Lady was anxious to bargain with these hostile actors. In response to the negative ad campaign leveled against her and her husband's attempts at reform, the First Lady accused the insurance industry of being greedy and deceptive, and asserted that their primary reason for opposing the legislation was a "desire to protect and maximize their profits" (Johnson \& Broder, 1996, p. 209). President Obama displayed adroitness in dealing with interest groups and lobbyists throughout his attempts at passing the ACA. Both president Obama and Democratic Congressmen recognized the necessity of bargaining with "hard-headed... [and] economically hefty stakeholders" (Jacobs \& Skocpol, 2012, p. 69). Taking into account the lessons learned from president Clinton's failure to pass the HSA, David Axelrod, a prominent White House Official rightly noted that there was "no chance at winning the necessary 60 votes in the Senate if interest groups were against you" (Jacobs \& Skocpol, 2012, p. 69).

In order to placate healthcare providers, the Obama administration promised that healthcare reform would provide $\$ 171$ billion for hospitals and \$228 billion for doctors (Abelson, 2010). In return, the American Hospital Association agreed to accept $\$ 155$ million less in Medicare payments over 10 years, while the American Medical Association agreed to receive $\$ 80$ billion less in payments. Large pharmaceutical companies struck a large bargain by agreeing to charge lower drug prices and pay fees that totaled $\$ 85$ billion over 10 
years in exchange for tens of billions of dollars in new customer prescriptions from the newly insured and from "filling the doughnut hole" to improve Medicare's prescription drug subsidies (Abelson, 2010). Stakeholders in the pharmaceutical industry also saw reform as a way to introduce rules protecting themselves against new competition from makers of cheaper generic drugs as well as a promise from the Obama administration that they would not support the importation of cheaper medications from other countries in spite of the fact that Obama pledged to allow this on the campaign trail in 2008 (Jacobs \& Skocpol, 2012, p. 71). Lastly, private health insurance companies stood to gain from the passage of the ACA, as the Obama administration granted these stakeholders with their "dearest [wish]" of requiring all Americans to have coverage under the highly contested individual mandate provision (Abelson, 2009). Again, this test of my hypothesis proves its applicability to the legislative process. By realizing the importance of interest groups, the Obama administration understood the necessity of acting in a way that was amenable to their interests. One need not look any further than the HSA and its failure to pass into law as a reminder of what is likely to happen when this rapport is non-existent.

Further distinguishing the two cases, and providing support for my hypothesis that the presence of a filibuster proof majority is of fundamental importance to the passage of presidential proposals, is the ideological spread in both the House and Senate throughout the attempts at passing both pieces of legislation. The ideological spread in Congress also opposes the counterhypothesis that a majority in both houses of Congress will enable a presidential proposal to succeed legislatively. I will test this aspect of my hypothesis by citing statistical data and empirical analysis that relates to both pieces of legislation.

The importance of the ideological spread in Congress was arguably more relevant to Clinton. Firstly, in the 103rd Congress, president Clinton was three seats short of having a filibuster proof majority in the Senate. ${ }^{1}$ Additionally, he had a much harder time in getting members of his own party on board with the legislation given the amount of dissension amongst Democrats in both chambers. To many observers, the HSA was bound to fail from the end of 1993 and onwards, as a "concerted partisan [campaign] against universal health care reform had locked into place and the support of middle-class Americans for ambitious health reforms had begun to slide inexorably downhill" (Skocpol, 1995). For most of 1993-1994, reform minded officials in the Democratic Party could not unite on basic "how-to" features of health reform, and president Clinton was unable to attract most of the Democrats in Congress to his specific approach (Skocpol, 1995). On the other side of the aisle, Newt Gingrich, who was then serving as the House Minority leader, was determined to scuttle the legislation, as he saw the failure of the legislation as the "necessary prelude to defeating the Democrats in the 1994 midterm elections" (Johnson \& Broder, 1996, p. 304). Given that Republicans in Congress were obdurate in their opposition right from the start, the complete and total unity of Democratic legislators was a bare minimum requisite need for the legislation to have a chance at success. The lack of a filibuster proof majority only exacerbated this, rendering it likely that the legislation was doomed to fail right at the outset.

In terms of convincing wavering Democratic legislators to vote for the ACA, president Obama was required to do a relatively small amount of coaxing in comparison to president Clinton. The ideological makeup in Congress was favorable to president Obama. In 2009, there were 75 more Democrats than Republicans in the House of Representatives, which afforded president Obama an unusually large majority (Jacobs \& Skocpol, 2012, p. 60). In the Senate, the election of Al Franken (D-MN) provided majority leader Harry Reid the

\footnotetext{
${ }^{1}$ Party Division in the Senate, 1789-Present. Retrieved December 3, 2016, from http://www.senate.gov/history/partydiv.htm
} 
possibility of securing a filibuster proof majority in the Senate in the event that he could unite all 58 Democrats and the two independents to vote for the legislation (Jacobs \& Skocpol, 2012, pp. 60-61). A simple meeting with members of Congress was generally enough to secure support for the legislation. The "Louisiana purchase", which involved Obama providing Landrieu with funds to offset the effects of Hurricane Katrina, was necessary to get Senator Mary Landrieu on board, while the "Cornhusker Kickback" was implemented to send extra Medicaid subsidies to Nebraska in order to secure the vote of Senator Ben Nelson (Jacobs \& Skocpol, 2012, p. 51).

On the whole, Democratic lawmakers were willing to sacrifice their hope of introducing a public option as away to guarantee that meaningful healthcare reform passed both chambers of Congress (Jacobs \& Skocpol, 2012, p. 63). During the passage of the ACA, Democratic lawmakers realized that a Canadian style single payer system was likely to never pass, and agreed to "start with what the United States already has in place and nudge things forward from there" (Jacobs \& Skocpol, 2012, p. 67). On the other side of the aisle, with only 41 seats in the Senate and 178 seats in the House, the Republicans possessed the weakest minorities in decades and were therefore unable to mount the same sort of counter insurgency that they launched in opposition to Clinton ${ }^{2}$. Due to this sizable majority, the legislation managed to pass despite being opposed by 34 "blue dog Democrats" in the House ${ }^{3}$.

This methodology shows that my hypothesis has a high degree of credibility in terms of domestic issues, and counters my alternative hypothesis involving the widespread belief that a presidential proposals chance at success can be determined simply by looking at the makeup of Congress. However, this methodology does not refute one of my counter hypotheses involving the increased ability of the president to pass legislation in the sphere of foreign policy. Canes-Wrone et al's., statistical proof that Congress grants increased authority to the president in terms of foreign policy reveals a degree of limitation to my hypothesis (Canes-Wrone, Howell, \& Lewis, 2008, p. 14). One would not have to look any further than the 134 Democrats who voted in favor of the USA Patriot Act as an example of how members of Congress will vote with the president of another party in certain cases $^{4}$, and that such votes can be for policies that later become widely unpopular.

\section{Conclusion}

After conducting this research design, it is clear that my hypothesis has a degree of qualitative support. When president Obama possessed a filibuster proof majority in the Senate, had the support of the overwhelming majority of his own party, and compromised with economically powerful interest groups, his chances at achieving legislative success were ultimately realized. When president Clinton lacked all three of these things, the odds of his HSA being passed into law were essentially zero. This research should be expanded on to provide a greater degree of quantitative support, as doing so could provide further support for my claim that the overall body of research on the subject of presidential Congressional relations leaves certain inadequacies. In order to do this, researchers would be wise to gather data on presidential proposals spanning a number of different administrations, determine the ideological spread in Congress in each specific case, unearth

\footnotetext{
2 Party Division of the House of Representatives. Retrieved December 5, 2016, from http://history.house.gov/Institution/Party-Divisions/Party-Divisions/

3 HR. 3590 (111th): Patient Protection and Affordable Care Act. Retrieved December 6, 2016, from https://www.govtrack.us/congress/votes/111-2010/h165

4 HR 3162 "USA Patriot Act of 2001" voting record. Retrieved December 12, 2016, from https://votesmart.org/bill/votes/8289\#.WFBilKMZORs
} 
the behavior of interest groups throughout the overall effort, and find out whether or not the bill passed into law. A regression that measures statistical significance between these variables can provide further insight into whether this design possesses a high degree of external validity.

This research design also has a number of implications for the political process. While one would be wise to bet on a Democratic Congressman supporting a proposal of a Democratic president (and opposing a proposal coming from a Republican president), this support is, in many cases, contingent on the factors contained in my hypothesis. Congressmen belonging to a president's party will have trepidation about supporting one of his proposals in the event that interest groups establish a united front against the proposal. As a corollary of this, it is logical to say that the notion that a partisanship dictates the legislative fortunes of all presidential proposals is incomplete.

This research design also furthers our understanding of one of the most fundamental theoretical debates in American political life, which is the hyper-partisanship. After consulting with this design, the question surrounding how polarized American lawmakers are becomes more complicated. This allegedly unconditional partisanship was absent during president Clinton's attempts at passing the HSA, and has been notably absent in times of national crises as well. If this design does nothing else, my hope is that it forces the reader to acknowledge that when it comes to understanding presidential proposals and the legislative process broadly, there is much more to disentangle than many Americans know.

\section{References}

Abelson, R. (2009, September 10). President's speech allays some fears in the health industry. New York Time. Retrieved December 5, 2016, from http://www.nytimes.com/2009/09/11/health/policy/11insure.html?mcubz=0

Abelson, R. (2010, March 21). In health care overhaul, boons for hospitals and drug makers. New York Times. Retrieved December 5, 2016, from http://www.nytimes.com/2010/03/22/business/22bizhealth.html?mcubz=0

Canes-Wrone, B., Howell, W. G., \& Lewis, D. E. (2008). Toward a broader understanding of presidential power: A reevaluation of the two presidencies thesis. The Journal of Politics, 70(1), 1-16.

Jacobs, L. R., \& Skocpol, T. (2012). Healthcare reform and American politics: What everyone needs to know. New York, NY: Oxford University Press.

Johnson, H., \& Broder, D. S. (1996). The system: The American way of politics at the breaking point. Boston: Little, Brown \& Company.

Kingdon, J. W. (1989). Congressmen's voting decisions (3rd ed.). Ann Arbor, MI: University of Michigan.

Lee, F. (2008a). Dividers, not uniters: Presidential leadership and senate partisanship, 1981-2004. The Journal of Politics, 70(4), 914-928.

Lee, F. (2008b). Agreeing to disagree: Agenda content and senate partisanship, 1981-2004. Legislative Studies Quarterly, 33(2), 199-222.

Lee, F. (2009). Beyond ideology: Politics, principles, and partisanship in the U.S. senate. Chicago, IL: University of Chicago Press.

Skocpol, T. (1995). The rise and resounding demise of the Clinton plan. Health Affairs, 14(1), 66-85. 